\title{
PENYULUHAN TEKNIK BUDIDAYA TANAMAN OBAT DI PEKARANGAN SEBAGAI UPAYA KETAHANAN KELUARGA TERHADAP COVID-19 DI KECAMATAN ALALAK
}

\author{
Muhammad Helmy Abdillah, Herry Iswahyudi, Mila Lukmana, Linda \\ Rahmawati, Dewi Amelia Widiyastuti, Zuliyan Agus Nur Muchlis Majid \\ Program Studi Budidaya Tanaman Perkebunan, Politeknik Hasnur \\ Email : abdillah.helmy21@gmail.com
}

\begin{abstract}
ABSTRAK
Pencegahan dan pengobatan gejala Covid-19 terus diupayakan oleh semua pihak melalui berbagai tindakan, salah satunya mengkonsumsi hasil tanaman yang dikatagorikan sebagai tanaman obat. Hal ini dipercaya dapat meningkatkan imunitas maupun menyembuhkan gejala yang dirasa menyerupai gejala Covid-19 seperti demam, batuk, bersin, diare serta kelelahan letih dan lunglai. Tingginya minat terhadap hasil dan produk turunan dari tanaman tersebut membuat sebagian produk cukup sulit untuk ditemukan, oleh karena itu perlunya melakukan budidaya secara mandiri untuk mengurangi ketergantungan terhadap produk yang dijual dipasaran. Kecamatan Alalak juga menjadi wilayah transit yang ingin melakukan perjalanan ke Marabahan, Banjabaru, Banjarmasin dan wilayah Kalimantan Tengah, sehingga mudahnya masyarakat setempat berinteraksi langsung dengan orang dari luar daerah. Oleh karena itu, dengan kondisi yang demikian perlu dilakukan pengembangan dan pemberdayaan masyarakat yang berorientasi pada pemanfaatan pekarangan sebagai tempat bertani sederhana, terlebih meninjau letak Kecamatan Alalak yang menjadi bagian wilayah strategis khusus Provinsi dan mewabahnya pandemi Covid-19 pada wilayah transmisi, guna membangun dan memperkuat ketahanan kesehatan keluarga. Tujuan kegiatan ini untuk menyebarluaskan pengetahuan tentang teknik budidaya tanaman obat dan menilai kebermanfaatannya melalui metode analisis kualiatif - kuantitatif dengan pengisian angket pra dan pasca kegiatan. Hasil dari kegiatan ini adalah terdapat respon positif terhadap tingkat pengetahuan dan kebermanfaatan pasca kegiatan.
\end{abstract}

Keywords : Covid-19, Tanaman obat, Ekstensifikasi

\begin{abstract}
All parties continue to strive to prevent and treat the symptoms of Covid-19 through various actions, one of which is consuming plant products that are categorized as medicinal plants. This is believed to increase immunity and cure symptoms that feel like symptoms of Covid-19 such as fever, coughing, sneezing, diarrhea, and tiredness and weakness. The high interest in products and derivative products from these plants makes some products quite difficult to find, therefore it is necessary to carry out cultivation independently to reduce dependence on products sold in the market. Alalak sub-district is also a transit area wishing to travel to Marabahan, Banjabaru, Banjarmasin, and the Central Kalimantan region, making it easy for local people to interact directly with people from outside the region. Therefore, under such conditions it is necessary to develop and empower communities that are oriented towards the use of yards as simple farming places, especially considering the location of Alalak District which is part of the special strategic area of the Province and the outbreak of the Covid-19 pandemic in
\end{abstract}


the transmission area, to build and strengthen. family health resilience. The purpose of this activity is to disseminate knowledge about medicinal plant cultivation techniques and to assess their usefulness through qualitative-quantitative analysis methods by filling out pre and post-activity questionnaires. The result of this activity is that there is a positive response to the level of knowledge and usefulness after the activity.

Keywords : Covid-19, Medicinal plants, Extensification

\section{PENDAHULUAN}

Pencegahan dan pengobatan gejala Covid-19 terus diupayakan oleh semua pihak melalui berbagai tindakan, salah satunya mengkonsumsi hasil tanaman yang dikatagorikan sebagai tanaman obat. Hal ini dipercaya dapat meningkatkan imunitas maupun menyembuhkan gejala yang dirasa menyerupai gejala Covid-19 seperti demam, batuk, bersin, diare serta kelelahan letih dan lunglai. Tingginya minat terhadap hasil dan produk turunan dari tanaman tersebut membuat sebagian produk cukup sulit untuk ditemukan, oleh karena itu perlunya melakukan budidaya secara mandiri untuk mengurangi ketergantungan terhadap produk yang dijual dipasaran. Kecamatan Alalak juga menjadi wilayah transit yang ingin melakukan perjalanan ke Marabahan, Banjabaru, Banjarmasin dan wilayah Kalimantan Tengah, sehingga mudahnya masyarakat setempat berinteraksi langsung dengan orang dari luar daerah. Oleh karena itu, dengan kondisi yang demikian perlu dilakukan pengembangan dan pemberdayaan masyarakat yang berorientasi pada pemanfaatan pekarangan sebagai tempat bertani sederhana, terlebih meninjau letak Kecamatan Alalak yang menjadi bagian wilayah strategis khusus Provinsi dan mewabahnya pandemi Covid-19 pada wilayah transmisi, guna membangun dan memperkuat ketahanan kesehatan keluarga.

Bercocok tanam dapat dilakukan di pekarangan rumah (Dewi \& Widiyawati, 2019; Mundiyah et al, 2020). Pada masa sekarang, idealnya dapat menanam tanaman pangan dan obat sebagai ikhtiar memperkuat ketahanan keluarga dengan persediaan pangan dan obat secara mandiri untuk meminimalisir kontak langsung dan menghemat ekonomi keluarga. Tanaman obat yang dapat ditanam di pekarangan rumah seperti kunyit, temulawak, dan jahe (tanaman rimpang/empon-empon), daun sirih maupun jenis tanaman obat lainnya sangat mudah dibudidayakan, apalagi 
menggunakan campuran tanah dengan kompos dari biomassa tanaman yang diperkaya dengan mikroorganisme (Mariana \& Budi, 2018).

Secara umum, pembudidayaan tanaman dapat dilakukan dengan metode vegetatif, seperti metode cangkok, rimpang dan setek. Lahan pekarangan rumah yang dimanfaatkan untuk budidaya tanaman obat tersebut akan berfungsi sebagai apotik hidup untuk anggota keluarga (Sari et al, 2015; Qomariah \& Lesmayati, 2020). Keluarga akan memiliki akses tanaman berkhasiat di pekarangan rumah untuk pemeliharaan kesehatan anggota keluarga sehingga dapat mengurangi penggunaan obat-obatan kimiawi secara berlebihan (Sarjiyah et al, 2016; Saputera et al, 2020). Tujuan kegiatan ini untuk menyebarluaskan pengetahuan tentang teknik budidaya tanaman obat dan menilai kebermanfaatannya melalui metode analisis kualiatif - kuantitatif dengan pengisian angket pra dan pasca kegiatan.

\section{METODOLOGI PELAKSANAAN}

Pengabdian kepada Masyarakat dilaksanakan di Aula Kantor Kecamatan Alalak pada 23 Desember 2020. Pelaksanaan program pengabdian ini dilaksanakan dengan metode penyuluhan dan demonstrasi. Acara berlangsung dengan memaparkan materi dengan ceramah dan dilakukan bersamaan dengan demonstrasi nya oleh tim mahasiswa sambal dilakukan tanya jawab. Kegiatan utama yang dilaksanakan dalam progam ini adalah (1) memberikan penyuluhan tentang pemanfaatan pekarangan rumah yang dapat difungsikan sebagai lahan budidaya tanaman obat, teknik perbanyakan tanaman dan manfaat beberapa tanaman obat sebagai imunomodulator. Pada kegiatan ini dibagi menjadi 2 tahap. Tahap ke-1 yakni survey sederhana sebagai pendahuluan. Hasil survey pendahuluan dan wawancara dengan Kepala Seksi Pelayanan dan Sekretaris Kecamatan Alalak serta informasi dari LPj Bupati Kabupaten Barito Kuala tahun 2017 untuk menggali masalah mitra dan menemukan potensi dari Kecamatan Alalak terkait luas daerah, jumlah penduduk, potensi daerah dan kedudukan daerah bagi Provinsi Kalimantan Selatan (Pemkab Batola, 2017). Tahap ke-2 yakni merancang dan melakukan kegiatan yang terdiri dari beberapa tahap yang dapat dilihat pada Tabel 1 yang dimodifikasi dari Febliza et al (2019). 
Table 1. Tahap kegiatan penyuluhan teknik tanaman obat

\begin{tabular}{|c|c|c|}
\hline No. & Tahapan & Kegiatan \\
\hline 1 & Tahapan Persiapan & $\begin{array}{l}\text { - Penyusunan modul teknik budidaya (tindak } \\
\text { agronomi) } \\
\text { - Penyusunan instrumen evaluasi berupa angket } \\
\text { kegiatan pengabdian } \\
\text { - pengumpulan alat dan bahan presentasi dan } \\
\text { peraga (demonstrasi) }\end{array}$ \\
\hline 2 & Tahapan Pelaksanaan & $\begin{array}{l}\text { - Pengisian angket pra-kegiatan oleh warga } \\
\text { yang hadir } \\
\text { - Penyampaian materi teknik budidaya / tindak } \\
\text { agronomi tanaman obat } \\
\text { - Demonstrasi dan praktik oleh warga }\end{array}$ \\
\hline 3 & $\begin{array}{l}\text { Tahapan Evaluasi dan } \\
\text { Pembuatan Laporan } \\
\text { Kinerja }\end{array}$ & $\begin{array}{l}\text { - Pengisian angket pasca kegiatan oleh warga } \\
\text { yang hadir } \\
\text { - Analisis hasil evaluasi pra-kegiatan dan pasca } \\
\text { kegiatan } \\
\text { - penyusunan laporan kinerja kegiatan }\end{array}$ \\
\hline
\end{tabular}

Pada tahap pelaksanaan dan evaluasi, dibagikan lembar angket kegiatan, yang mencantumkan beberapa pertanyaan tentang pengetahuan yang dimiliki masyarakat yang hadir sebelum dan sesudah disampaikannya materi penyuluhan. Beberapa pertanyaan dalam angket ini digunakan sebagai parameter untuk evaluasi dan kebermanfaatan kegiatan. Metode analisis kualiatif - kuantitatif (Kariadinata \& Abdurahman, 2012) dengan pengisian angket pra dan pasca kegiatan digunakan untuk mengukur respon kegiatan penyuluhan terhadap pengetahuan teknik budidaya tanaman obat, kebermanfaatan penyuluhan ini dan minat para peserta untuk mencobanya sendiri.

\section{HASIL DAN PEMBAHASAN}

Kegiatan pengabdian kepada ini dilakukan dengan cara penyuluhan menggunaan metode ceramah dan demonstrasi. Metode ceramah dilakukan untuk menyampaikan berbagai informasi umum mengenai teknik budidaya tanaman obat dan juga secara khusus menyampaikan beberapa teknik perbanyakan tanaman Kencur (Kaempferia galanga L) dengan metode rimpang serta teknik perbanyakan tanaman Sirih Merah (Piper crocatum) dengan metode setek. Secara umum tahapan perbanyakan Kencur dapat dilihat pada Gambar 1. 


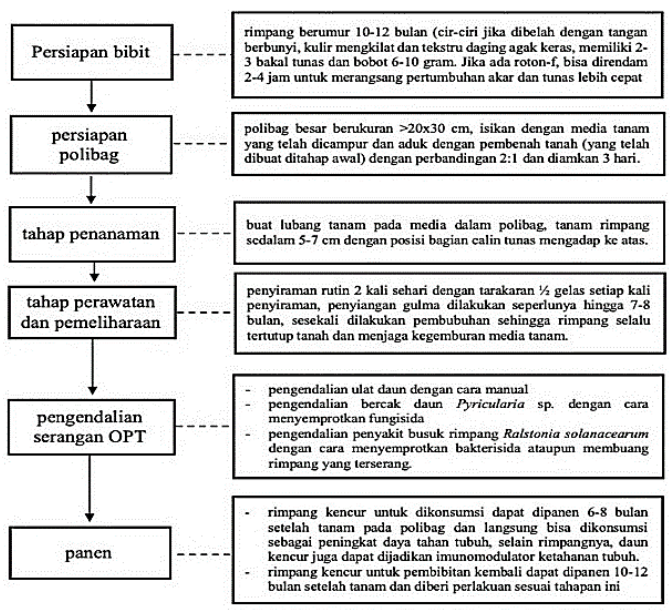

Gambar 1. Metode perbanyakan dan

budidaya Kencur dengan teknik

$$
\text { rimpang }
$$

Teknik perbanyakan dan budidaya Sirih Merah dapat dilihat pada Gambar 2.

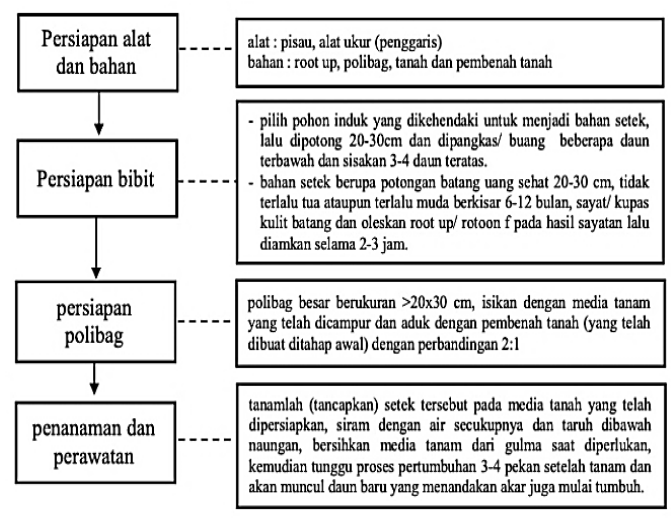

Gambar 2. Metode perbanyakan dan budidaya Sirih Merah dengan teknik setek

Pada kegiatan ini disampaikan bahwa upaya pemanfaatan lahan pekarangan antara lain dengan mengusahakan komoditi yang lebih bernilai ekonomis dan juga bermafaat untuk kesehatan, apalagi dimasa pandemi Covid-19 yang belum tentu akan berakhir dalam waktu dekat. Penyuluhan ini mendorong masyarakat untuk membudidayakan tanaman obat secara mandiri dengan cara menggunakan bagian dari satu tanaman untuk menghasilkan beberapa tanaman yang tumbuh baik dan hasilnya lebih banyak. Teknik perbanyakan vegetatif dengan rimpang dan setek merupakan cara praktis efisien agar tanaman cepat tumbuh dan dapat segera dikonsumsi (Lestari \& Hutami, 2005; Werdhany et $a l, 2008)$ Selain itu, hasil tanaman obat dapat dioptimalkan sebagai jamu yang berpotensi secara ekonomis meningkatkan pendapatan (Pratama, 2014).

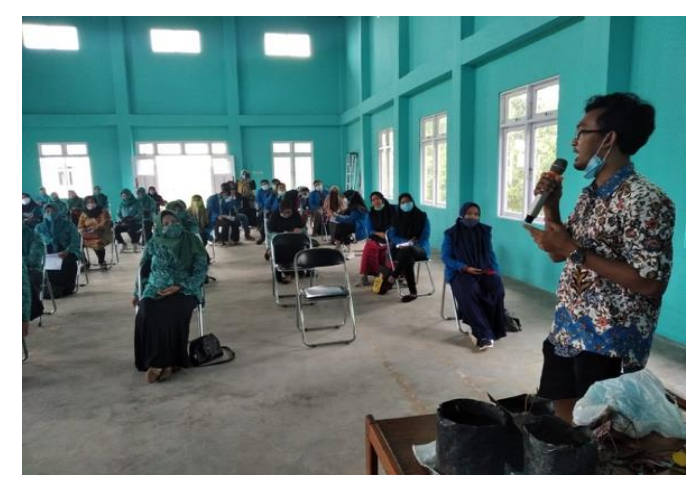

Gambar 3. Pemberian materi

$$
\text { penyuluhan }
$$

Evaluasi keberhasilan dari kegiatan penyuluhan ini dilakukan dengan cara menganalisis indikator perubahan dari masyarakat sebagai subjek yang disuluh, yakni respon terhadap pengetahuan yang disampaikan ke masyarakat. Dari 
diagram batang yang ditampilkan pada Gambar 4, menunjukkan bahwa 28 orang warga belum mengetahui cara budidaya tanaman obat dengan teknik kearifan lokal yang dimaksud pada materi yang akan disampaikan, sedangkan 6 orang cukup mengetahui teknik budidaya tanaman obat secara praktis.

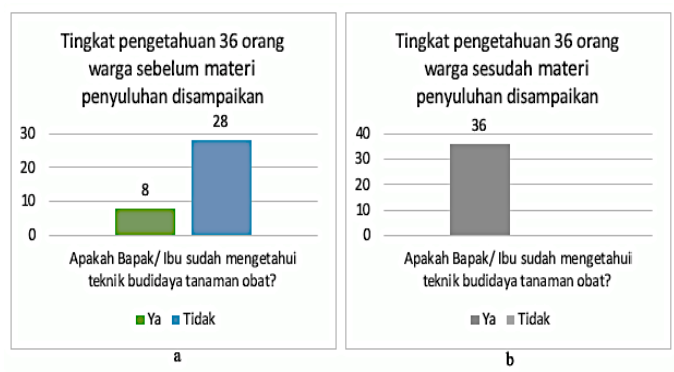

Gambar 4. Diagram hasil evaluasi angket

a) pra-kegiatan dan b) pasca kegiatan

Menurut Yulida, et al (2012), penyuluhan setidaknya membawa dampak positif terhadap perubahan pengetahuan masyarakat, diharapkan peran penyuluh sebagai agen perubahan dan penyebar informasi kepada masyarakat mampu mendorong semangat masyarakat untuk berinovasi. Masyarakat juga diharapkan lebih aktif menghadiri kegiatan dan menyampaikan pertanyaan dalam membangun pengetahuan bersama, meskipun pertanyaan yang digagas masih bersifat umum. Lebih dari itu, dampak positif yang terbentuk yakni dari yang tidak tahu menjadi tahu, dari yang hanya sekedar tahu kemudian akan mencoba serta dari yang telah mencoba akan menjadi semangat dalam melaksanakannya sebab didorong oleh kebersamaan teman sejawat dengan pemikiran untuk mencoba bersama, maju dan berkembang. Berdasarkan Gambar 5, menunjukkan bahwa ada respon positif terhadap kebermanfaatan kegiatan penyuluhan yang dilakukan.

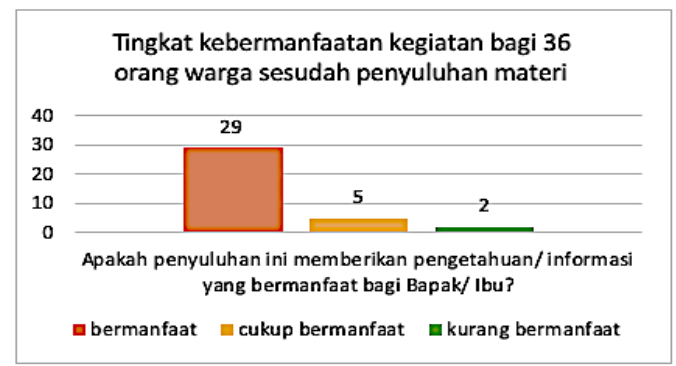

Gambar 5. Diagram hasil evaluasi angket pasca kegiatan penyuluhan

Hal ini terlihat pada antusiasme warga dalam menyimak, bertanya dan terlibat langsung melakukan peragaan yang didemonstasikan oleh tim dosen dan mahasiswa. Kebermanfaatan penyuluhan ini diungkapkan warga melalui pengisian angket pasca kegiatan. Jumlah responden yang menanggapinya dengan memberi jawaban memilih opsi bermanfaat sebanyak 29 orang, memilih opsi cukup bermanfaat sebanyak 5 orang. 


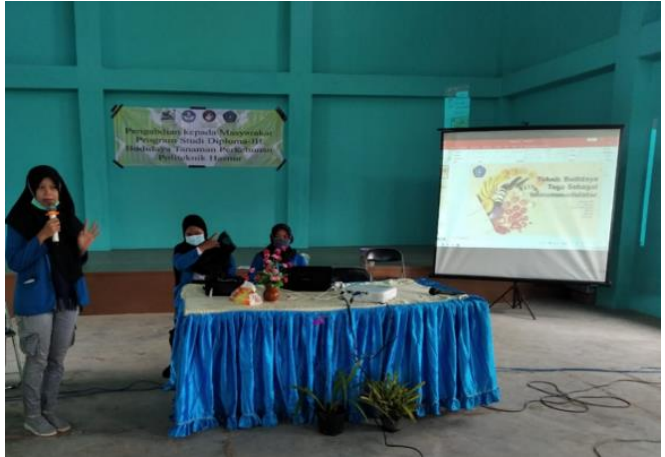

Gambar 6. Pemaparan materi oleh tim

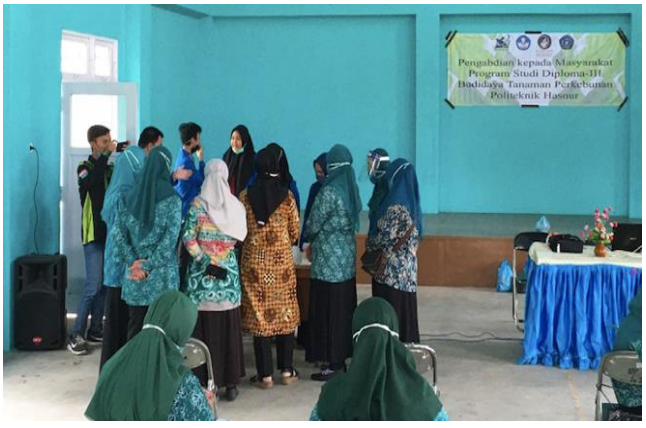

Gambar 7. Demonstarsi oleh tim dan antusiasme peserta secara bergantian

Dari analisis yang dilakukan, hasil ini terjadi karena sebagian besar warga yang mengikuti adalah anggota PKK Kecamatan Alalak yang memang memerlukan pengetahuan dan kemampuan untuk mengembangkan daerah/ desanya masing-masing. Menurut Bahua (2015) menyatakan bahwa kapasitas organisasi kemasyarakatan di suatu daerah sangat berperan besar dalam kemajuan pola pikir masyarakat, pengetahuan, kemampuan dan pergerakan dalam menginisiasi inovasi, sehingga anggota organisasi idealnya memiliki pengetahuan dan kemampuan yang bermafaat bagi diri sendiri dan orang lain.

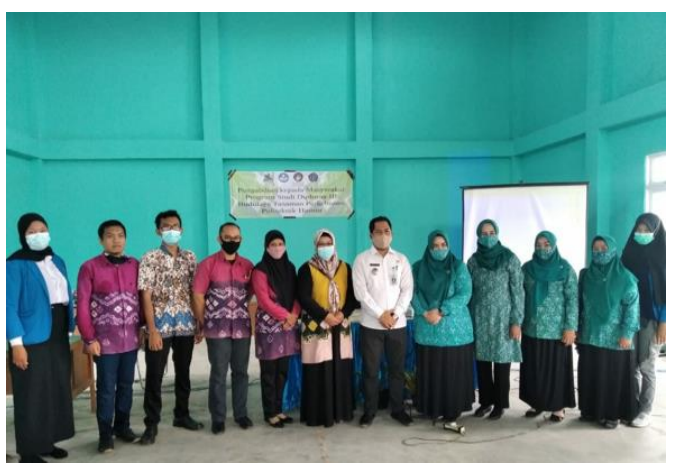

Gambar 8. Foto bersama tim PKM dengan Camat dan warga

Penyuluhan dilakukan untuk memberikan ilmu pengetahuan kepada masyarakat berskala kecil maupun menengah dengan tujuan meningkatkan pengetahuan dan perubahan sikap serta membentuk masyarakat yang berdaya saing dan mampu mengatasi permasalahan yang dihadapi saat ini dan mendatang sehingga diharapkan dapat mendukung pembangunan dan cita-cita nasional yang membentuk sebuah idealisme kemandirian negara. Dalam mengikuti kegiatan penyuluhan, masyarakat dituntut belajar sambil berbuat (learning by doing) atau melaksanakan materi penyuluhan pada saat demonstrasi maupun mengulangi/ melakukannya kembali didaerah/ rumahnya masing-masing. 


\section{KESIMPULAN}

Berdasarkan hasil kegiatan pengabdian kepada masyarakat ini, dapat disimpulkan :

1. Penyuluhan "Teknik Budidaya Tanaman Obat di Pekarangan sebagai upaya Ketahanan Keluarga terhadap Covid-19 di Kecamatan Alalak" meningkatkan pengetahuan tentang teknologi dan teknik budidaya tanaman obat beserta manfaatnya di pekarangan rumah masing-masing.

2. Terdapat respon positif terhadap tingkat pengetahuan dan kebermanfaatan pasca kegiatan penyuluhan.

\section{Saran}

1. Perlu adanya pelatihan yang terstruktur dan rutin serta pembinaan terhaap warga Kecamatan Alalak, terutama anggota PKK khususnya melakukan praktik teknik budidaya, pemanfaatan bahan local sebagai pembenah tanah untuk budidaya, serta perawatan, pemanenan dan pengolahan tanaman obat agar dapat dikonsumsi.

2. Penyuluhan kepada warga terutama anggota PKK di Kecamatan Alalak dalam budidaya tanaman obat keluarga diharapkan dapat terwujud dengan baik dengan adanya pemberian beberapa contoh tanaman obat yang dapat ditanam di pekarangan rumah masing-masing peserta serta beberapa bentuk olahan dalam bentuk serbuk dan simplisia yang sudah diberi keterangan manfaat dan cara pemakaiannya.

\section{UCAPAN TERIMA KASIH}

Tim penulis mengucapkan terimakasih pada Yayasan Hasnur Center melalui Politeknik Hasnur yang telah memberikan dana untuk kegiatan pengabdian kepada masyarakat.

\section{DAFTAR PUSTAKA}

Bahua MI. 2015. Penyuluhan dan Pemberdayaan Petani Indonesia. Ideas Publishing. ISBN : 978-602-1396-91-9.

Dewi SP, Widiyawai I. 2019. Pengenalan Teknologi Budidaya Tanaman Obat sebagai Upaya Pemanfaatan Lahan Pekarangan di Kelurahan Pabuwaran Purwokerto, Jawa Tengah. PANRITA ABDI: Jurnal Pengabdian Kepada Masyarakat, 3(2), 106-113.

Kariadinata R, Abdurahman M. 2012. Dasar-Dasar Statistik Pendidikan. (Cetakan ke-1). CV. Pustaka Setia. Bandung

Febliza A, Afdal Z, Oktariani. 2019. Pelatihan Pembuatan Kompos 
Menggunakan Effective Microorganisms (EM4) Bagi Guru-Guru Sd Negeri 18 Pekanbaru. Jurnal Pengabdian Untuk Mu Negeri, 3(2): 12-16.

Lestari EG, Hutami S. 2005. Produksi Bibit Kencur (Kaempferia galanga L.) Melalui Kultur Jaringan. Berita Teknologi, 7(6), 315-321.

Mundiyah IM, Sari NMW, Nabilah S, Suparyana PK. 2020. Pelatihan Budidaya Jamur Tiram Dengan Konsep Urban Farming Untuk Masyarakat Perkotaan. Jurnal Al-Ikhlas, 6(2):156-163.

Mariana, Budi IS. 2018. Penerapan Teknologi Pembuatan Trikompos di Desa Sungai Bokor Kalimantan Selatan. Jurnal Al-Ikhlas, 4(1):6-13.

Pemkab Barito Kuala. 2017. Laporan Keterangan

Pertanggungjawaban Bupati Barito Kuala. Pemerintah Kabupaten Barito Kuala. Kalimantan Selatan

Pratama D. 2014. Analisis Pendapatan dan Pemasaran Tanaman Kencur (Kaempferia galanga L.) di Kecamatan Argamakmur Kabupaten Bengkulu Utara. Skripsi Program Studi Agribisnis Jurusan Sosial Ekonomi Pertanian Fakultas Pertanian Universitas Bengkulu.

Sari ID, Yuniar Y, Siahaan S, Riswati R, Syaripuddin M. 2015. Tradisi Masyarakat dalam Penanaman dan Pemanfaatan Tumbuhan Obat Lekat di Pekarangan. Jurnal
Kefarmasian Indonesia, 5(2). https://doi.org/10.22435/jki.v5i 2.4407.123-132

Sarjiyah S, Samijo SG, Istiyanti E. 2016. Mewujudkan Desa Mandiri Pangan Melalui Pengelolaan Pekarangan. BERDIKARI : Jurnal Inovasi dan Penerapan Ipteks, 4(1), 13-22.

https://doi.org/10.18196/bdr.41 $\underline{2}$

Qomariah R, Lesmayati S. 2020. Budidaya Tanaman Obat di Lahan Pekarangan (Herbal Potensial untuk Meningkatan Sistem Imun Tubuh) pada website

http://kalsel.litbang.pertanian.g o.id/ind/index.php?option=com content \&view $=$ article \&id $=93$

3:administrator\&catid $=14:$ alsin $\underline{\text { \&itemid }=43}$ diakses pada 3 Desember 2020

Saputera MMA, Sari AK, Febrianti DR, Niah R, Kumalasari E. 2020. Program Bina Desa dalam Pemberdayaan Masyarakat untuk Pemanfaatan Tanaman Obat Keluarga di Desa Tatah Layap Kabupaten Banjar. Jurnal Al-Ikhlas, 6(1):48-53.

Werdhany Wi, Anthoni WSS, Setyorini W. 2008. Sirih Merah. Balai Pengkajian Teknologi Pertanian, Yogyakarta.

Yulida R, Al-Kausar, Marjelita L. 2012. Dampak Kegiatan Penyuluhan Terhadap Perubahan Perilaku Petani Sayuran di Kota Pekanbaru Indonesian. Journal of Agricultural Economics (IJAE) 3(1): 37-58. 